\title{
Study on Teenage Pregnancy
}

\section{Mrs Lakshmi KN*}

Principal, Vikram College of nursing, Mysuru, India

Submission: June 07, 2018; Published: June 15, 2018

*Corresponding author: Mrs Lakshmi KN, Principal, Vikram College of nursing, Mysuru, India, Email: lakshmiguru079@gmail.com

\section{Statement of the Problem}

"A study to assess the knowledge of nursing students regarding teenage pregnancy in Vikram college of nursing at Mysuru with a view to develop health education pamphlets".

\section{Objectives of the Study}

a. To assess the level of knowledge of nursing students regarding teenage pregnancy.

b. To find out the association between the knowledge regarding age, sex, religion, residence and type of family with their selected demographic variables.

\section{Operational Definitions}

a. Teenage pregnancy- Pregnancy occurs after puberty between the ages of 13-19 years.

b. Health education pamphlet- It refers to self learning information prepared by the investigator in English regarding teenage pregnancy.

c. Nursing students- The students who are studying BSc. Nursing in Vikram college of nursing.

\section{Assumptions}

The assumption of the study was

a. A health education pamphlet is an effective method to educate nursing students regarding teenage pregnancy.

\section{Delimitations}

The study is limited to students of $1^{\text {st }}$ year BSc. nursing students who are studying at Vikram Educational Trust, Mysuru.

\section{Hypothesis}

$\mathrm{H}_{1}$ : Level of knowledge of nursing students regarding teenage pregnancy will be significantly associated with their selected demographic variables viz. age, sex, religion, residence and type of family.

\section{Research Methodology}

The research design selected for the study is descriptive approach.

\section{Variables of the Study}

a. Dependent Variables: Knowledge of nursing students regarding teenage pregnancy.

b. Settings of the Study: Vikram Nursing college, mysuru.

\section{Sample and Sampling}

Sample is the subset of population. The sample of present study comprises of 40 students of $1^{\text {st }}$ year BSc Nursing who are studying in Vikram college of nursing at Mysuru.

\section{Sampling Technique}

Non-probability convenient sampling technique is used in the present study [1,2].

\section{Criteria for Sampling}

\section{Inclusion Criteria}

a. Students in the $1^{\text {st }}$ year BSc .

b. Students available at the time of data collection.

\section{Exclusion Criteria}

a. Students who are sick at a time of data collection.

\section{Data Collection Technique and Instrument}

\section{Part-A: Performa for Selected Demographic Variables}

It includes demographic variables like age, sex, religion, residence and type of family.

\section{Part-B: Structured Knowledge Questionnaire to Assess the Knowledge Regarding Teenage Pregnancy}

Teenage pregnancy questionnaire included definition,etiology,clinical features and management.

Scoring:

a. Good knowledge(16-20)

b. Poor knowledge(0-10)

c. Average knowledge(11-15) 
Results

Section 1: Table 1

Table 1: Frequency and percentage distribution of nursing students by age, sex, religion, residence and type of family: $n=40$.

\begin{tabular}{|c|c|c|}
\hline $\begin{array}{c}\text { Demographic } \\
\text { Variable }\end{array}$ & Frequency & Percentage \\
\hline Age in years & & \\
\hline $17-19 y e a r s$ & 35 & $87.50 \%$ \\
$20-23 y e a r s$ & 1 & $10 \%$ \\
$25-28 y e a r s$ & 10 & $2.50 \%$ \\
\hline Sex & 30 & $25 \%$ \\
\hline Male & & $75 \%$ \\
\hline Female & 25 & $62.50 \%$ \\
\hline Religion & 7 & $17.50 \%$ \\
\hline Hindu & 8 & $20 \%$ \\
\hline Christian & & \\
\hline Muslim & 23 & $57.50 \%$ \\
\hline Residence & 17 & $42.50 \%$ \\
\hline Rural & & \\
\hline Urban & 28 & $30 \%$ \\
\hline Type of family & 12 & \\
\hline Nuclear & & \\
\hline Joint & & \\
\hline
\end{tabular}

Section 2: Description of knowledge scores of nursing students regarding teenage pregnancy

Data presented in Table 2 shows that the mean knowledge score was 14.8 with standard deviation \pm 2.99 and median was 15 (Table 3).

Table 2: Mean, Median and Standard Deviation of knowledge score of nursing students regarding teenage pregnancy: $n=40$.

\begin{tabular}{|c|c|c|c|}
\hline Group & Mean & Median & Standard deviation \\
\hline Nursing students & 14.8 & 15 & \pm 2.99 \\
\hline
\end{tabular}

Table 3: Frequency (f) and percentage distribution (\%) of nursing students according to their level of knowledge regarding teenage pregnancy: $n=40$.

\begin{tabular}{|c|c|c|}
\hline Class interval & Frequency (f) & Percentage (\%) \\
\hline $0-10$ (Poor) & 5 & $12.5 \%$ \\
\hline $11-15$ (Average) & 15 & $37.5 \%$ \\
\hline $16-20$ (Adequate) & 20 & $50 \%$ \\
\hline
\end{tabular}

Section 3: Association between Level of Knowledge of Nursing Students Regarding Teenage Pregnancy and their Selected Demographic Variables

Association of level of knowledge of nursing students regarding teenage pregnancy with their selected demographic variables such age, sex, religion, residence and type of family was found out by computing chi-square (Table 4).

Table 4: $n=40$.

\begin{tabular}{|c|c|c|c|c|c|c|c|c|}
\hline \multirow{2}{*}{ Sl. no } & \multirow{2}{*}{ Selected demographic variables } & \multicolumn{3}{|c|}{ Knowledge scores } & \multirow{2}{*}{ Chi-square } & \multirow{2}{*}{ Df } & \multirow{2}{*}{ Table value } & \multirow{2}{*}{ Significance } \\
\hline & & Poor & Average & Adequate & & & & \\
\hline \multirow[t]{4}{*}{1} & Age in years: & & & & & & & \\
\hline & $17-19$ yrs. & 3 & 15 & 17 & & & & \\
\hline & $20-23$ yrs. & 2 & 0 & 2 & 9.49 & 4 & 0.05 & S \\
\hline & $25-28$ yrs. & 0 & 0 & 1 & & & & \\
\hline \multirow[t]{3}{*}{2} & Sex: & & & & & & & \\
\hline & Male & 3 & 4 & 3 & & & & \\
\hline & Female & 3 & 11 & 16 & 5.99 & 2 & 0.05 & NS \\
\hline \multirow[t]{4}{*}{3} & Religion: & & & & & & & \\
\hline & Hindu & 2 & 13 & 10 & & & & \\
\hline & Christian & 0 & 0 & 7 & 9.49 & 4 & 0.05 & NS \\
\hline & Muslim & 3 & 2 & 3 & & & & \\
\hline \multirow[t]{3}{*}{4} & Residence: & & & & & & & \\
\hline & Rural & 3 & 10 & 10 & & & & \\
\hline & Urban & 3 & 4 & 10 & 5.99 & 2 & 0.05 & NS \\
\hline \multirow[t]{3}{*}{5} & Type of family: & & & & & & & \\
\hline & Nuclear & 6 & 10 & 12 & & & & \\
\hline & Joint & 0 & 4 & 8 & 5.99 & 2 & 0.05 & NS \\
\hline
\end{tabular}

S- Significant

NS- Nothing Significant 


\section{Conclusion}

The present study showed the level of knowledge of nursing students regarding teenage pregnancy among 40 nursing students $12.5 \%$ having poor level of knowledge, $37.5 \%$ were having average level of knowledge and $50 \%$ of nursing students having good level of knowledge.

\section{Recommendations}

a. A large scale study can be conducted to generalize the findings.

b. A study can be conducted on effectiveness of health education pamphlet related to improve the knowledge regarding teenage pregnancy for the nursing students. c. A similar study can be conducted by adopting experimental approach.

d. This study can also be conducted on other health demographics.

\section{References}

1. Dutta DC (2013) Text Book of Obstetrics, including perinatology and contraception, Calcutta, New central book agency.

2. Health in South Asia (2017) Incidence of teenage pregnancy in India, Public Health Specialist, India.

\section{Your next submission with Juniper Publishers will reach you the below assets}

- Quality Editorial service

- Swift Peer Review

- Reprints availability

- E-prints Service

- Manuscript Podcast for convenient understanding

- Global attainment for your research

- Manuscript accessibility in different formats

( Pdf, E-pub, Full Text, Audio)

- Unceasing customer service

Track the below URL for one-step submission https://juniperpublishers.com/online-submission.php 